\title{
An Analytical Study on Role of Government in Accelerating Higher Education in India
}

\author{
Ankita Srivastava ${ }^{1}$, Dr. Daya Shankar Yadav ${ }^{2}$ \\ ${ }^{1}$ National Institute of Medical Science University, Shobha Nagar- Delhi Highway Jaipur, Rajasthan (India) \\ ${ }^{2}$ Raja Balwant Singh Management Technical campus, Khandari Agra, Uttar Pradesh (India)
}

\begin{abstract}
The role of government is of visionary, and to make more objective based actions rather than the subjective actions and plans. India which is the 7th largest and 2 nd most populated country with over 1.25 billion people there are 22 million graduates passing every year and 250,000 students taking higher education overseas annually. The country needs more conducive and congenial environment to breed neo working force, with the high technical skills \& the standards.The key problems confronting higher education in India are quality, equity, access and financing. In the last 10 years, there has been a massive ad hoc expansion of Central Universities, IITs and Indian Institutes of Management resulting in a shortage of faculty by 40 to 50 percent.Also the mushrooming of the pvt.Universities. Now the role of government has become more participatory and decision oriented to meet out the requirement of the innovative and existing world. In the present study, an attempt has been made to examine the various issues concerning the role of government of India in Education sector. We wish to study the role of the GOVERNMENT in Higher education, with changing environment focusing on the university's position in the newly emerging knowledge infrastructure.
\end{abstract}

Keywords: Indian higher education statistics, UGC, vision 2020

"Looking ahead, I believe that the underlying importance of higher education, of science, of technology, of research and scholarship to our quality of life, to the strength of our economy, to our security in many dimensions will continue to be the most important message."

Charles Vest

\section{Objectives of Study}

- To explore the role of government in higher education system.

- To assess the future of higher education till 2020.

- To study the various challenges faced by the government.

- To arouse interest in the discussion of basic questions relating to the role of government of India in higher education.

\section{Introduction}

The roots of the higher education is an ancient old, at the beginning of the earlier civilization our country has been the pioneer to spread, the aroma and the vivid tastes of the knowledge engulfed in the petals of its teachings, at various Universities of Nalanda and Taxela, to the setup of the modern Indian University of Mumbai 1857 and the new SAARC University in 2014.

The need of the higher education made the first union government to have a statutory organization called UNIVERSITY GRANT COMMISSION (UGC) came into the existence in 1956, till date it is functioning under the ministry of Human and Resource development with the objectives of coordinating, \& maintaining the University standards.

As, India got the independence sixty eight years before, and we have marched from the five year plan to the fourteen year plan. The government has made the certain bodies like AICTE to monitor, the technical and management education in India. Also national commission on higher education has been set up by the ministry. But still there is an rift of the proper objectives with respect to the industry and technology which needs immediate measures to be addressed. So that we can put ourselves and young generation in the main stream of developed and powerful Nation.

"Our university system is, in many parts, in a state of disrepair...In almost half the districts in the country, higher education enrollments are abysmally low, almost two-third of our universities and 90 per cent of our colleges are rated as below average on quality parameters... I am concerned that in many states university appointments, including that of vice-chancellors, have been politicized and have become subject to caste and communal considerations, there are complaints of favoritism and corruption"

To get the proper feel of this ailment, let us see the objective and subjective analysis, with the role and participation of the government currently in 2015 we stand with. Now in India there are 700 degree granting institutions and around 35500 affiliated colleges. Statistics are as below:

\section{Indian Higher Education Statistics}

700 - Degree granting institutions, 35,500 - Affiliated Colleges

\section{Subject Percentage}




\section{International Journal of Science and Research (IJSR) \\ ISSN (Online): 2319-7064}

Index Copernicus Value (2013): 6.14 | Impact Factor (2014): 5.611

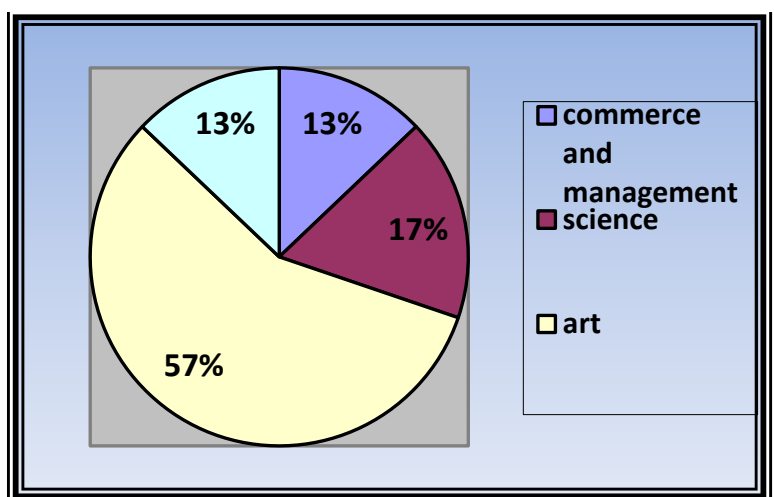

Figure 1: Data has been taken from UGC

A University is a place where new ideas sprout, strike roots and grow with strapping. It is a unique space, which covers the entire Universe of knowledge. It is a place where creative minds converge, interact with each other and construct visions of new realities. Established notions of truth are challenged in the pursuit of knowledge.

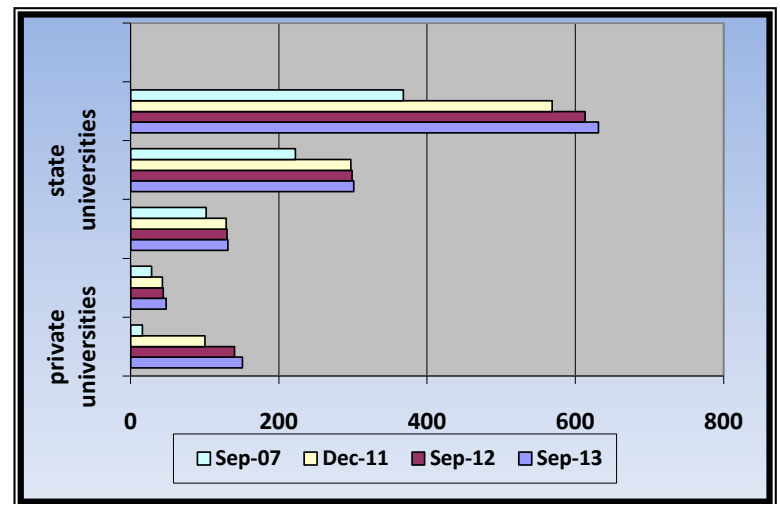

Figure 2: Data has been taken from UGC

To be able to do all this, Universities should have autonomous spaces. They are diverse in settings in which they grow. This diversity reflects the organic links that they have with their surroundings, which are not only physical but cultural as well. Through research and teaching, they create, evaluate and bring about advances in knowledge and culture. The principle of moral and intellectual autonomy from political authority and economic power is ingrained in the very idea of the University, their design and organization, reflecting the unique historical and socio-cultural. This autonomy ensures freedom in research and training and it is expected that the governments and the society would respect this fundamental principle. Teaching and research have to be inseparable, because the task of the University is not only to impart knowledge to young people but also to give them opportunities to create their own knowledge. Active and constant engagement with the young minds and hearts of the society also implies that the universities are to serve the society as a whole, and in order to achieve this, considerable investment in continuing education is essential.

The slow but increasing democratization of higher education in India has meant that the University is no longer the preserve of the children of the elite, or of the educated/professional middle-class. As more youngsters from a different segment of society enter the Universities, they look at higher education as a means to transcend the class barriers. Consequently, University education is no longer viewed as a good in itself, but also as the steppingstone into a higher orbit of the job market, where the student expects a concrete monetary return, and consequently in this perception, the University of Today is expected to be in tune with the emerging needs of the society. Even so, graduates should be sufficiently exposed to interdisciplinary experiences, which can sustain them when the demands of a particular job market changes.

These are: one, socio-cultural aims of higher education; two, academic excellence; and three, institutional self-reform.

\section{Legal Setup}

The Constitution of India offers a framework for aims of education. The socio-cultural aims enshrined in the Constitution assign a transformative role to education. Therefore, in the first parameter we suggest the application of criteria, which derive their value from the categories in terms of which the inequality and social injustice prevailing in Indian society are commonly understood and expressed.

According to the University Grants Commission, in its guidelines for considering any proposal for declaring an institution a deemed university under Section 3 of the UGC Act, "the institution should generally be engaged in teaching programmers and research in chosen fields of specialization which are innovative and of very high academic standard at the master's and research levels. It should also have a greater interface with society through extramural extension and field-action related programmers."

Faculty wise student enrollment in higher education 2012-13

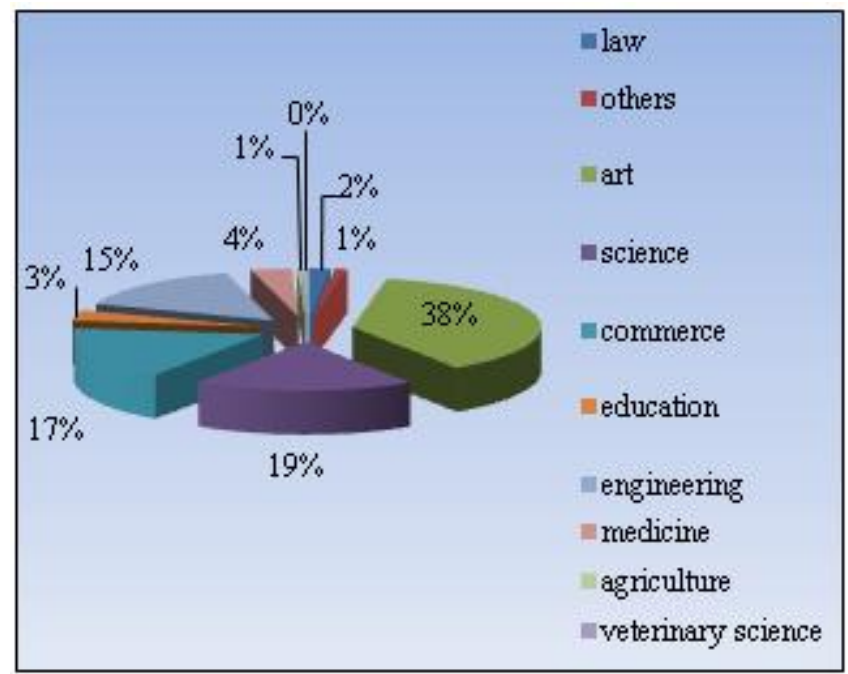

Figure 3

Source - UGC

We see from the above statics that the faculty and student ratio is very broader, it reflects the no of the faculty engaged in various courses. Now we can easily access the requirement and the role of the government to meet out the proper ratio. 
International Journal of Science and Research (IJSR)

ISSN (Online): 2319-7064

Index Copernicus Value (2013): 6.14 | Impact Factor (2014): 5.611

Table 1:

\begin{tabular}{|c|c|c|c|c|c|c|}
\hline & In University Departments \& University Colleges & \multicolumn{2}{|c|}{ In Affiliated Colleges } & Total & \multirow{2}{*}{$\begin{array}{c}\text { Percentage in } \\
\text { affiliating Colleges }\end{array}$} \\
\hline & Numbers & Percentage & Numbers & Percentage & & \multirow{2}{*}{08.46} \\
\hline Professors & 16244 & 21.00 & 23708 & 6.1 & 39952 & \\
\hline Readers & 24468 & 31.63 & 94016 & 23.8 & 118484 & 25.12 \\
\hline Senior Lecturers & 11850 & 15.33 & 59505 & 15.1 & 71355 & 15.12 \\
\hline Lecturers & 22868 & 29.56 & 203425 & 51.5 & 226293 & 47.95 \\
\hline Tutor/ Demonstrators & 1920 & 2.48 & 13927 & 3.5 & 15847 & 03.35 \\
\hline Total & 77350 & 100.00 & 394581 & 100.00 & 471931 & 100.00 \\
\hline
\end{tabular}

*Prepared by Dr. Education .com

Table 2

\begin{tabular}{|c|c|c|c|c|c|}
\hline LEVEL & $\begin{array}{c}\text { Student Enrollment } \\
(2012-13)\end{array}$ & $\begin{array}{c}\text { Student Graduates } \\
(2012-13)\end{array}$ & $\begin{array}{c}\text { Avg. Duration of } \\
\text { Program }\end{array}$ & $\begin{array}{c}\text { Student Enrollment } \\
(2012-13 \text { Est. })\end{array}$ & $\begin{array}{c}\text { Student Earning Degree } \\
(2014-15 \text { Est })\end{array}$ \\
\hline Graduates (Bachelor's) & $\mathbf{1 7 4 5 6}$ & $\mathbf{5 5 7 6}$ & & $\mathbf{2 3 0 8 6}$ & $\mathbf{7 3 7 5}$ \\
\hline $\begin{array}{c}\text { Graduate } \\
\text { (Bachelors Three Years) } \\
\text { B.A, B. COM, B.SC. EST. }\end{array}$ & $\mathbf{1 4 5 4 7}$ & $\mathbf{4 8 4 9}$ & $\mathbf{3}$ Years & $\mathbf{1 9 2 3 8}$ & $\mathbf{6 4 1 3}$ \\
\hline $\begin{array}{c}\text { Graduate } \\
\text { (Bachelor's Engg..) EST }\end{array}$ & $\mathbf{2 9 0 9}$ & $\mathbf{7 2 7}$ & $\mathbf{4}$ Years & $\mathbf{3 8 4 8}$ & $\mathbf{1 6 4 8}$ \\
\hline Post Graduate (Master's) & $\mathbf{2 4 9 2}$ & $\mathbf{1 2 4 6}$ & $\mathbf{2}$ Years & $\mathbf{3 2 9 6}$ & $\mathbf{5 3}$ \\
\hline Research (DOCTORAL) & $\mathbf{1 6 1}$ & $\mathbf{4 0}$ & $\mathbf{4}$ Years & $\mathbf{2 1 3}$ & $\mathbf{9 0 7 6}$ \\
\hline
\end{tabular}

*Prepared by Dr. Education .com

As, there has been a political stability in a state in 2014 , decision making powers rests in the ministry for the face lift of this sector. India need the more concrete approach to bridge gap between the three sectors i.e. primary, secondary and tertiary which are also the engine of the growth, more and more quality teachers are required to meet out the vacuum existing. As we see from the UGC data all the fields contributing with their disciplines, this will lead to increase the faculty and student ratio.

\section{Research Methodology}

The methodology deployed for this survey consisted of primary research, with insights being captured through questionnaires and face -to- face discussions. Inputs from potential customers to this industry have also been collated, with respect to their key concerns while considering education in India .Our analysis and findings are based on consensus findings from the survey and are supported by quantitative and qualitative inputs from the respondents. The data presented in this report is based on information received from the respondents. The general intent of this descriptive study was threefold. Therefore a systematic and organized methodology was obtained for the research study. A survey design was used to obtain the required information. The population for this study comprised of employees working in education sector. A sample size of 100 was chosen for this study. Simple random sampling technique was used to gather data from the respondents, because of which respondents diverged from officers of higher education department, faculty, owner of institutions, colleges, universities and student of higher education. Out of 100 respondents there are 10 officers from higher education, 5 owners, 45 faculties and 40 student.

Primary and secondary data fall within the scope of statistics and can be used as part of a research method. The collected data may assist a company in measuring, assessing and discussing the results of data collection for whatever purposes the information is required. This is where the differences between the two become relevant as some companies need a direct approach and therefore use primary data sources whereas others need previously collected information - that is, secondary data - which they can apply to their own situation.

Primary data can be explained, therefore, as information collected from sources such as personal interviews, questionnaires or surveys with a specific intention and on a specific subject, and observation and discussion by the researcher him or herself, which information is then assessed by that person. It is a direct approach and, as it is tailored to a company's particular needs, reveals apparently, much-needed information to that company which started the research;that is, the results are used for the purpose for which they were originally intended. It can be a lengthy process but does provide first-hand information. In this study we use less primary data and more secondary data.

Secondary data is information that is already available somewhere, whether it be in journals, on the internet, in a company's records or, on a larger scale, in corporate or governmental archives. Secondary data allows for comparison of, say, several years worth of statistical information relating to, for example, a sector of the economy, where the information may be used to measure the effects of change or whatever it is that is being researched. Sometimes both methods are used in research as companies want to measure their own responses and previouslygenerated responses from which a comparison can be made.

\section{Conclusion}

We have to admit rationally, that our country has a weak higher education system. There is no doubt that the Indian higher education system, given the enormity of the challenges it is facing, needs a drastic overhaul. Apart from various short-term issues there is a serious threat to the very

\section{Volume 5 Issue 2, February 2016}




\section{International Journal of Science and Research (IJSR) \\ ISSN (Online): 2319-7064 \\ Index Copernicus Value (2013): 6.14 | Impact Factor (2014): 5.611}

idea of the University and its values in our country today, with globalization, technological and demographic changes, also with the growing economic importance of knowledge ,these are making higher education reforms more urgent and challenging than in past. In brief, higher education in India suffers from a lack of a democratic leadership that understands its true nature. Those heading these institutions are usually the favorites of those in power (political or money). They largely implement the agenda of their masters and, therefore, do not feel the need to be accountable to the academic community. To them, accountability is personal and not institutional or societal. They undermine the autonomy of the democratic bodies of universities, like the academic council through threats and inducements. Government must take the practical measures to revive pedagogy and administrative bottlenecks. So that, there must not be erosion of the autonomy and accountability in institutions of higher learning, both from within and without. This is the biggest challenge before an India that aspires to arrive on the world stage.

My main object for writing this paper has been to arouse interest in the discussion of the basic questions relating to the role of government of India in education. If this found hope were to materialize, my labour would be more than adequately rewarded.

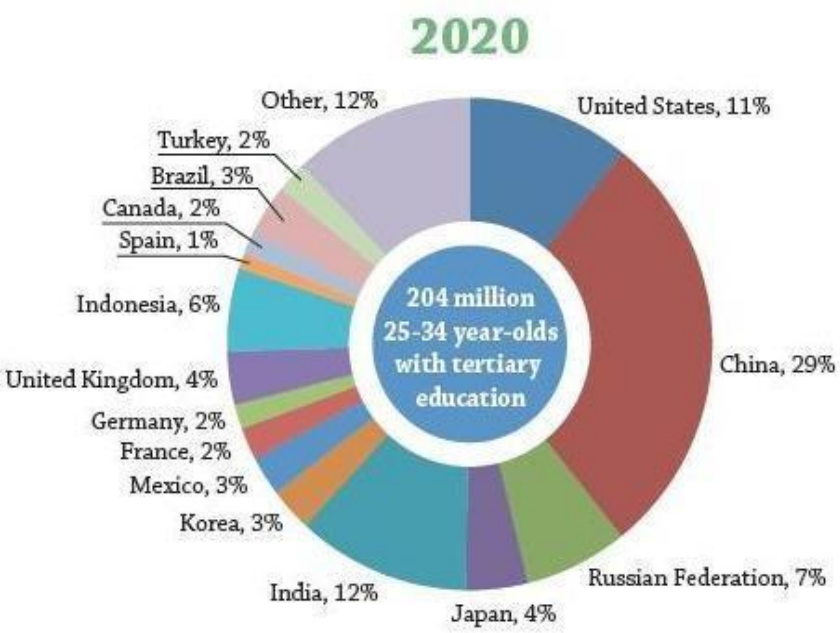

Figure 3: Vision 2020

(SWATCH SIKHSHA ABHIYAN)

\section{References}

[1] Charles "Chuck" Marstiller Vest (September 9, 1941 December 12, 2013) was a U.S. educator and engineer. He served as President of the Massachusetts Institute of Technology from 1990 until December 2004.

[2] Altbach, Philip G. and N. Jayaram. 2010. 'Can India Garner The Demographic Dividend'. The Hindu, December.

[3] http://www.thehindu.com/opinion/lead/article924112.ece?h omepage =true (accessed 21 October 2012).

[4] Blessinger, Patrick and Enakshi Sengupta. 2012. 'Is Malaysia the Regional Leader in International Higher Education?' The Guardian, 2 July. http://www.guardian.co.uk/higher-educationnetwork/blog/2012/jul/02/higher-education-in-malaysia (accessed 21 October 2012).

[5] Ernst \& Young-FICCI. 2009. 'Making The Indian Higher Education System Future Ready'. Paper presented at 'FICCI
Higher Education Summit', 6-7 November, New Delhi. 2011. 'Private Sector Participation in Indian Higher

[6] Education'. Paper presented at 'FICCI Higher Education Summit', 11-12 November, New Delhi.

[7] Estacio. 2012. 'Education Market, Industry Overview'. Estacio Company website, 27 January.

[8] http://www.estacioparticipacoes.com.br/estacio2010/web/c onteudo_en.asp?idioma $=1 \&$ tipo $=30 \quad 243 \&$ conta $=44$ (accessed 21 October 2012).

[9] Holzhacker, Denilde, Olena Chornoivan, Demet Yazilitas, and Khishibbuyan Dayan-Ochir. 2009. 'Privatization in Higher Education: Cross-Country Analysis of Trends, Policies, Problems and Solutions', Institute for Higher Education Policy.

http:// www.ihep.org/assets/files/publications/mr/(Issue_Brief)

[10] http://www.dreducation.com/

[11] Patrick Manu (2000), Educational Marketing, University News, Vol.38, p-3

[12] Singh Amrik (1982), Universities and Research, AIU

[13] Shah S Y (1986), New Technologies in Higher Education, AIU [13] Singh Amrik\& Sharma G D (1981), Universities and colleges finances, AIU

[14]Powar K B (2000), Higher Education for Human Development,AIU

[15] Psacharopoulous George \&Woodhall Maureen (1985), Education for development - an analysis of Investment choices.

[16] Watkins Kevin (2000), The Oxfam education report, Oxfam publication

[17] Allaway William H \&Hallam C Shorrock (1985), Dimensions ofInternational Higher Education, West view press

[18] UNESCO (1998), report on Higher Education in the Twentieth First Century Vision \& Actions held at Paris 5$9^{\text {th }}$ Oct 1998,UNESCO

[19] Country paper (1998), Higher Education in India: Vision \& Action, presented in UNESCO world conference of Higher Education inthe Twenty-first century, Paris 5-9 ${ }^{\text {th }}$ Oct 1998 , NationalCommission for Cooperation with UNESCO

[20] NegiUshaRai\&BhallaVeena (1999), Effectiveness and Quality inHigher Education, AIU [21] ShafiZeenat S (2001), Reforms and Innovations in Higher Education, AIU

[21] ShafiZeenat S (2003), Privatisation of Higher Education, AIU [23] Koul B N \& et al (1998), Studies in Distance Education, AIU

[22] Rowntree Derek (1981), A Dictionary of Education [25] Sharma Rita (2004), Assessment and Accreditation in Higher Education, AIU

[23] BhallaVeena\& et al (1998), Accountability and Autonomy in Higher Education, AIU

\section{Author Profile}

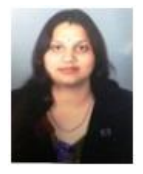

Ankita Srivastava received B.Com and MBA(HR and Finance) degrees in management from Raja Balwant Singh degree college in 2006, and Raja Balwant Singh Management And Technical Campus , Agra in 2009 respectively. After completing MBA she is now working with Sanjay Institute Of Engineering And Management, Mathura and she is having $7 \mathrm{yrs}$ of experience in teaching various management subjects. She is about to accomplish Doctorate in Philosophy (Ph.D) in Human Resource from National Institute Of Medical Science(NIMS) University, Jaipur. 